\title{
Influence of barley, corn and rice flour on physical, chemical and sensory characteristics of gluten-free bread
}

\author{
Md. Abdul Wazeda,b,*, Md. Rakibul Islam ${ }^{b}$ \\ a Department of Food Science and Engineering, German University Bangladesh (GUB), Gazipur-1702, Bangladesh \\ b Department of Food Engineering and Technology, Hajee Mohammad Danesh Science and Technology University (HSTU), Dinajpur-5200, Bangladesh \\ *Corresponding author email: hredoyfpe@gmail.com
}

Doi: 10.2478/mjhr-2021-0008

\section{Abstract:}

People suffering from the celiac disease have to apply a strict gluten-free diet because this is the only effective management. Nowadays, the increasing incidence of celiac disease promotes worldwide interests for various desirable gluten free products. As a consequence, food processing researchers have been seeking to develop high-quality gluten-free bread. Cereals having gluten such as wheat must be removed from the diet for the clinical and histological improvement. So, the purpose of this study was to determine the physical, chemical and sensory properties of gluten-free bread produced with barley ( $\mathrm{T}_{1}$ ), corn $\left(\mathrm{T}_{2}\right)$ and rice $\left(\mathrm{T}_{3}\right)$ flours instead of wheat flour, using the $1.5 \%$ xanthan gum. The chemical and sensory attributes of bread were evaluated by AOAC method and hedonic test, respectively. Obtained results showed that sample $\mathrm{T}_{3}$ had the highest contents of crude protein (7.94\%), ash (2.51\%) and carbohydrate (78.31\%) as compared to other samples, while fat was lower $(2.01 \%)$. Regarding moisture, breads prepared with the three different flours were not statistically different at the significance level of $\mathrm{p}<0.05$. However, they differed significantly regarding the specific volume and bake loss. Data also revealed that gluten-free bread, treatment $\mathrm{T}_{3}$ presented the best parameters, being preferred by the sensory evaluation panel, followed by treatment $\mathrm{T}_{1}$ and $\mathrm{T}_{2}$. The overall assessment pointed that the resulting breads treatment $\mathrm{T}_{3}$ was best for all physico-chemical characteristics and, in general, resulted in good sensory behavior, indicating that it could be a promising alternative to wheat flour.

Keywords: Celiac Disease, Gluten-free bread, Cereal flours, Different characteristics of gluten-free bread.

\subsection{Introduction}

Celiac disease is a severe genetic autoimmune disorder, caused by a dietary intolerance to gluten proteins found in all wheat types and closely related cereals such as barley and rye [1,2,3]. Celiac patients have the only effective treatment is a strict gluten-free diet throughout the lifetime [4, 5]. Therefore, gluten-free products, especially bakery products, were initially designed for celiac patients. At present, the demand for gluten-free products keep increasing, and is purely motivated by health concerns. As a consequence, many researchers have been carried out to develop gluten-free bakery products in order to offer a wide variety of gluten-free products with good nutritional quality, textural properties, palatability and sensory as well as long shelf life [6-11]. Gluten is composed of alcohol-soluble prolamins, which consist of gliadin fraction, and alcohol-insoluble glutelins, which consist of glutenin fraction, portions that trigger the symptoms in wheat, rye, spelt, oat and barley [12]. The small ingestion amounts of gluten can have serious health problems for celiac patients. Therefore celiac patients must avoid the oral ingestion of gluten [13] and gluten-free food products must be produced in such a way as to provide the conditions appropriate to the legislation and the amount of gluten must not exceed the amount specified in quality assurance legislations [14]. On the other hand, the production of high-quality gluten-free products made from ingredients other than wheat flour brings together major technological challenge and poor nutritional attributes [15]. Attempts are thus made to adopt methods that could produce cereal based gluten-free products with technological properties comparable to their gluten-containing counterparts and minimum compromises with quality [16]. Some novel techniques; such as usage of pseudocereals, flours of different legumes and flours of fruits and vegetables, hydrocolloids, emulsifiers, and applying different processing techniques such as; combination of infrared-microwave baking and extrusion cooking are often used to overcome these problems and to become better the quality of gluten-free food products [17]. Bread is considered a staple food worldwide [18, 19].

It has been regarded for centuries as one of the most popular and appealing food products both because of its relatively high nutritional value and its unique sensory characteristics (texture, taste, and flavor) [20]. The major attributes to determine the physical quality of breads are appearance, color and specific volume. According to Itthivadhanapong and Sangnark [21], the physical quality of breads often depends on many factors such as the ingredients used, the aeration of batters, and the techniques applied during mixing. Wheat flour is one of the main ingredients used to produce bread. For this reason, celiac patients are not able to consume this baked product [10]. Therefore, gluten-free breads have been commercially manufactured to resemble those made from wheat flour [10]. In the preparation of gluten-free baked products for celiac sufferers, cassava, maize, potato, or rice starch are widely used instead of wheat flour [22]. Gluten-free breads formulated from rice flour with gums had more bright color, mild taste, ease of digestion and hypoallergenic property $[23,24]$. The sensory parameters of gluten-free bread made from potato starch, corn starch, and corn meal with guar gum, xanthan gum, and pectin as gluten replacers in a various amount were studied by Gambus et al. [6].Very few studies for the production of corn and barley bread as glutenfree foods have been carried out because of corn's own distinctive flavor [25, 26]. However, the properties of gluten-free foods obtained from corn have similar quality attributes compared to the foods made from wheat flour. Gluten free- bread is rarely or not practiced in Bangladesh. It was very much liked by celiac patient who do not like to have wheat bread. This may create a new image for processing of a bakery product by using various gluten free cereal grains flour. This will have a direct impact on consumer's food selection and will increase their awareness of the health ben efits of processed bakery product in the prevention of chronic diseases. Therefore, the aim of this research was to study the different characteristics of three gluten-free bread formulations prepared with cereal flours (Rice, corn and barley) to develop new formulations that could substitute wheat flour, as an alternative product for celiac sufferers.

\subsection{Materials and methods}

The experiment was conducted in the laboratory of the Department of Food Engineering and Technology under the faculty of Engineering, Hajee Mohammad Danesh Science and Technology University, Dinajpur, Bangladesh.

\subsection{Sample Collection}

Gluten-free flours were purchased from a commercial market and transported to the laboratory. Sieving of flours for the removal of physical impurities. All other ingredients were purchased from commercial sources or directly from the suppliers, keeping the same specification in all experiments. Distilled 
water was used for all analysis. Polypropylene bags, aluminum foil paper and standard grade chemicals required for the work done were used form the laboratory stock.

\subsection{Material}

The ingredients used were: rice flour, corn starch, barley starch, granulated white sugar, dried

milk, iodized refined salt, baking powder, egg, xanthan gum, yeast, distilled water and flavoring agents.

\subsection{Experimental Treatments}

Three formulations were prepared, namely barley flour based (Treatment $\mathrm{T}_{1}$ ), corn flour based (Treatment $\mathrm{T}_{2}$ ) and rice flour based (Treatment $\mathrm{T}_{3}$ ). The basic replacing formulation for the loaf of bread was determined based on several preliminary assays. Ingredients for each formulation and their concentrations are listed in Table 1.

Table 1. Basic formulation used for preparation of gluten-free bread.

\begin{tabular}{lc}
\hline Ingredients & Composition (\%) \\
\hline Flour* & 100 \\
Yeast & 4.5 \\
Sugar & 6.0 \\
Salt & 1.8 \\
Xanthan gum & 1.5 \\
Milk powder & 1.0 \\
Baking powder & 2.5 \\
Egg & 100 \\
Flavoring agent & 1.0 \\
\hline
\end{tabular}

*Barley, corn or rice flour.

\subsection{Baking procedure}

The general technological scheme used to make the gluten-free bread is presented in Figure 1. To prepare the dough's of gluten- free breads, ingredients were weighed and mixed, adding first the dry ingredients, followed by yeast, shortening and water at $25 \pm 1^{\circ} \mathrm{C}$. Kneading was done during $1 \mathrm{~min}$ at low speed and $3.5 \mathrm{~min}$ at medium speed. After homogenization, the batter was proofed at $37^{\circ} \mathrm{C}$ and $85 \%$ relative humidity for 45 min. The dough's are cut into loaves, which baked at $200^{\circ} \mathrm{C}$ for $30 \mathrm{~min}$ in an electric oven. Breads were cooled down at room temperature for 2 hours and were then sliced and wrapped up in polypropylene bags.

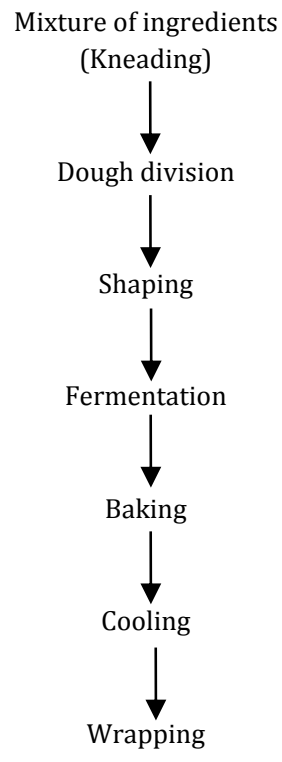

Figure 1. Flow chart of bread preparation.

\subsection{Analytical methods}

\subsubsection{Baking characteristics}

Loaf volume was measured by small seeds displacement method [27]. A container was used to measure the volume using small grains. Rapeseeds were poured into the container of known volume until the bottom was covered. The loaf was placed inside the container which was then filled to the top with more seeds. The extra rapeseeds, which equal the loaf volume, were measured in a graduated cylinder. The specific volume of the loaf was calculated using the following formula [28]:

Specific volume $\left(\mathrm{cm}^{3} / \mathrm{g}\right)=\frac{\text { Volume }(\mathrm{cm} 3)}{\text { Weight }(\mathrm{g})}$

The initial batter weight and the weight of bread after cooling were measured, and the bake loss was calculated using the formula [28]:

Bake loss $(\%)=\frac{\text { Initial weight of batter }- \text { weight of bread after cooling }}{\text { Initial weight of batter }} \times 100$ 
Proximate analyses of the samples were carried out using official AOAC methods for moisture, crude fat, ash and crude protein [29]. A nitrogen to protein conversion factor of 6.25 was used. Carbohydrate was calculated by difference.

\subsubsection{Organoleptic properties of produced breads}

Gluten free bread loaves were sensory evaluated after baking by twenty panelists according to the method described by Kramer and Twigg [30].

\subsection{Statistical Analysis}

Results were analyzed by analysis of variance (ANOVA) and least significance difference (LSD) using the general linear models procedure of Statistical Analysis System (SAS, 8 version). LSD values were used for comparison of sample data and evaluations were based on a significance level of $\mathrm{p}<0.05$

\subsection{Results and discussion}

\subsection{Baking characteristics}

Baking characteristics of gluten-free breads are shown in Table 2. Loaf specific volume is considered as one of the most important criteria in evaluating bread quality since it provides quantitative measurements of baking performance [31]. According to He and Hoseney [32], the capability to retain gas can be expressed in terms of bread volume. The changes in volume values are reflected in specific volume [33]. Table 2 indicates that the specific volume was lower $(p<0.05)$ in $\mathrm{T}_{2}$ than in $\mathrm{T}_{1}$ and $\mathrm{T}_{3}$ recipes and showed a significant difference only for rice flour $\left(\mathrm{T}_{3}\right)$ with the highest value $3.31 \mathrm{~cm}^{3} / \mathrm{g}$. Differences in bread volume can also be observed in Figure 2. The results were harmonized to others found by Abou-Zaid et al. [34]. However, specific volumes of glutenfree breads containing rice flour showed higher value than the findings reported by Matos et al. [10] in which their rice-based breads incorporated with different protein sources had specific volume of $1.54 \mathrm{~cm}^{3} / \mathrm{g}$. This finding shows that rice flour could be a good flour substitute for wheat flour in producing gluten-free bread. Generally, volume depends on gas formation, which depends on many factors, such as yeast, fermentable sugars, baking powder and pH, and gas retention. The presence of emulsifiers also affects bread volume [28, 35]. However, these values of specific volume were not satisfactory when compared to the specific volume obtained for an ordinary thin loaf prepared with plain flour, for which the mean value was $6.00 \mathrm{~cm}^{3} / \mathrm{g}$, according to Machado [36]. Some special bread exhibited specific small volumes $\left(\mathrm{cm}^{3} / \mathrm{g}\right)$, that is, they were denser and more compact, although these characteristics did not interfere with their acceptability by the consumers, according to Matz [37]. The barley flour bread $\left(\mathrm{T}_{1}\right)$ and corn flour bread ( $\left.\mathrm{T}_{2}\right)$ presented lower volumes than rice flour breads $\left(\mathrm{T}_{3}\right)$, but no significant differences $(p>0.05)$ were seen between samples.

Table 2. Baking characteristics of bread.

\begin{tabular}{|c|c|c|c|}
\hline \multirow[b]{2}{*}{ Treatment Code } & \multicolumn{3}{|l|}{ Baking characteristics } \\
\hline & Loaf specific volume $\left(\mathrm{cm}^{3} / \mathrm{g}\right)$ & $\begin{array}{l}\text { Bake loss } \\
\text { (\%) }\end{array}$ & $\begin{array}{l}\text { Moisture } \\
\text { (\%) }\end{array}$ \\
\hline $\mathrm{T}_{1}$ & $2.66 \pm 1.5^{\mathrm{b}}$ & $14.69 \pm 1.0^{\mathrm{b}}$ & $42.12 \pm 1.5^{\mathrm{a}}$ \\
\hline $\mathrm{T}_{2}$ & $2.53 \pm 0.2^{\mathrm{b}}$ & $13.87 \pm 1.2^{\mathrm{a}}$ & $41.06 \pm 0.2^{\mathrm{a}}$ \\
\hline $\mathrm{T}_{3}$ & $3.31 \pm 0.2^{\mathrm{a}}$ & $13.11 \pm 0.7^{\mathrm{a}}$ & $41.30 \pm 0.2^{\mathrm{a}}$ \\
\hline
\end{tabular}

Mean value \pm standard deviations of three replicates. Values labeled with a different letter in the same column are significantly different $(p<0.05)$. Barley flour based: $\mathrm{T}_{1}$; Corn flour based: $\mathrm{T}_{2}$; Rice flour based: $\mathrm{T}_{3}$.

Moisture content is the main parameter of food products that influence their shelf life. According to Rakcejeva et al. [38], the shelf life of products with high moisture content is shorter than that with lower moisture. Gluten free bread with the share of xanthan gum not exceeding $1.5 \%$, revealed comparable moisture (40-45\%) and similar to the previous findings [39]. No significant differences ( $p>0.05)$ were found in moisture content values of the three breads analyzed.
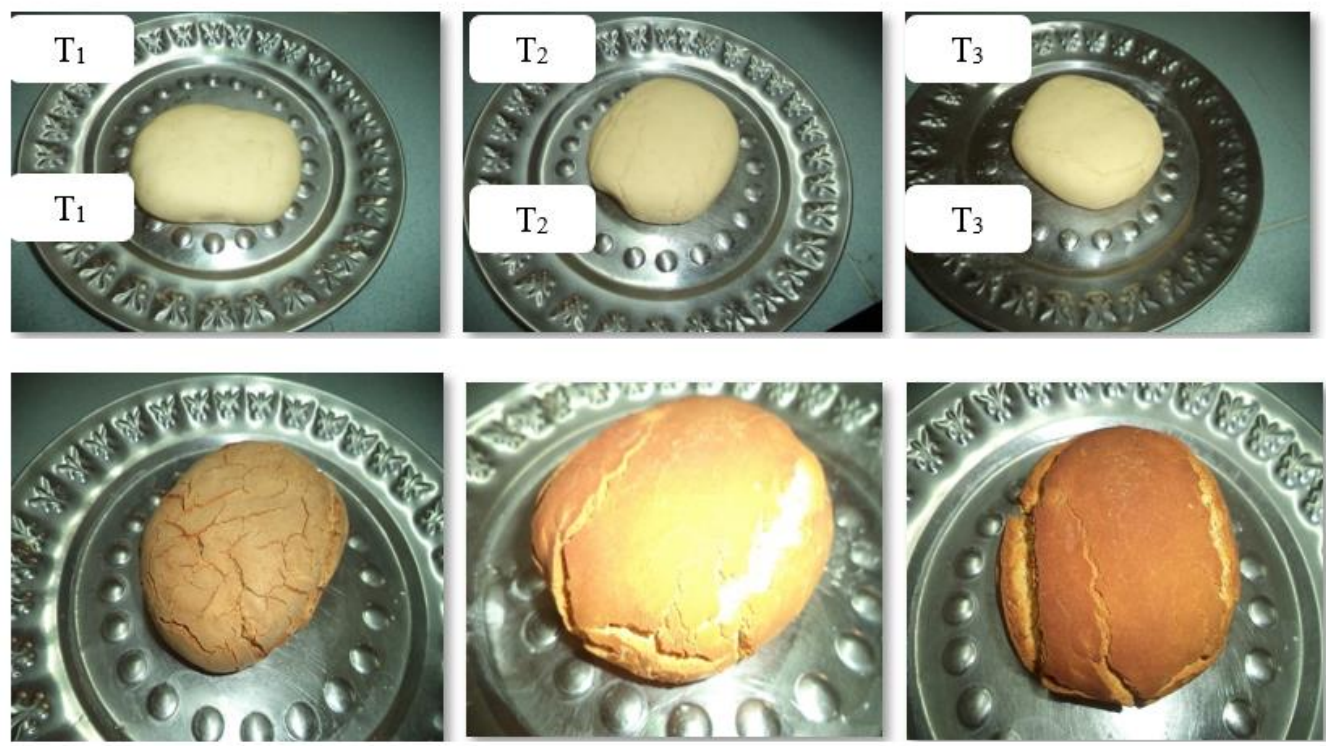

Figure 2. Gluten-free dough and bread of different treatment. Barley flour based: $\mathrm{T}_{1}$; Corn flour based: $\mathrm{T}_{2}$ and Rice flour based: $\mathrm{T}_{3}$. 
Bake loss is another important parameter related to bread quality because it is highly related with the firming process in starch-based systems [28]. Regarding to bake loss, $\mathrm{T}_{2}$ and $\mathrm{T}_{3}$ had lower values, 13.87 and 13.11, respectively, because of the low initial $\%$ of water and the high $\%$ of fiber contained in corn and rice flour, which absorbs water and helps to its retention during baking. The total baking loss of gluten-free bread developed in this study was lower than that of gluten-free bread developed by Pastuszka et al. [39].

\subsection{Chemical analysis}

The proximate contents of barley flour $\left(T_{1}\right)$, corn flour $\left(T_{2}\right)$ and rice flour $\left(T_{3}\right)$ bread are presented in Table 3 . There was important significant differences $(\mathrm{p}<0.05)$ among the proximate composition of all the gluten free bread samples. This table indicates that, the carbohydrate, protein and ash content of treatment $\mathrm{T}_{3}$ were higher than those of treatment $\mathrm{T}_{1}$ and $\mathrm{T}_{2}$. The results are agreement to the results of Hussein et al., Jancurová et al. and Abugoch et al. [40-42]. In this study, the gluten-free breads shows the great variation in the nutrient composition, being starchy based foods low in proteins and fat content and high in carbohydrate content. The protein contents of the composite breads ranged from 6.78-7.94\%, was found to be the highest in $\mathrm{T}_{3}$ while $\mathrm{T}_{2}$ showed the lowest values. This increase in the protein content must be associated to the presence of milk powder and egg proteins in the formulation, since those ingredients are used as protein sources in gluten free breads [43, 44]. Hegazy et al. [45] also found higher amount of protein content in rice flour and corn starch gluten-free bread formulations when compared to wheat flour control bread probably due to the addition of defatted soy and chickpea flours substituting part of wheat flour in yeast leavened bread making.

Table 3. Chemical composition of gluten-free bread.

\begin{tabular}{lllll}
\hline \multirow{2}{*}{ Treatment Code } & \multicolumn{4}{l}{ Chemical composition (\%) } \\
\cline { 2 - 5 } & Protein & Fat & Ash & Carbohydrate \\
\hline $\mathrm{T}_{1}$ & $7.61 \pm 0.5^{\mathrm{a}}$ & $2.64 \pm 1.5^{\mathrm{a}}$ & $1.8 \pm 1.3^{\mathrm{c}}$ & $74.14 \pm 1.1^{\mathrm{c}}$ \\
$\mathrm{T}_{2}$ & $6.78 \pm 0.9^{\mathrm{b}}$ & $2.67 \pm 1.2^{\mathrm{a}}$ & $2.3 \pm 0.2^{\mathrm{b}}$ & $76.26 \pm 0.9^{\mathrm{b}}$ \\
$\mathrm{T}_{3}$ & $7.94 \pm 0.2^{\mathrm{a}}$ & $2.01 \pm 1.1^{\mathrm{b}}$ & $2.51 \pm 1.2^{\mathrm{a}}$ & $78.31 \pm 0.7^{\mathrm{a}}$
\end{tabular}

Mean value \pm standard deviations of three replicates. Values labeled with a different letter in the same column are significantly different $(p<0.05)$. Barley flour based: $\mathrm{T}_{1}$; Corn flour based: $\mathrm{T}_{2}$; Rice flour based: $\mathrm{T}_{3}$.

Treatment $\mathrm{T}_{3}$ presented the lowest values of fat content (2.01\%), which agrees with the absence of fat ingredient in the formulation. Conversely, $\mathrm{T}_{2}$ showed the highest fat value (2.67\%), due to the contribution of the vegetable oil in these gluten-free bread formulations. Slightly variations were observed in ash contents that ranged from 1.80 to $2.51 \%$. Treatment $\mathrm{T}_{3}$ had the highest ash content, mainly derived from the level of salt. Bilgiçli [46] also found an ash amount increase in buckwheat flour, corn starch and rice flour pasta formulations when compared to wheat flour control pasta. The total carbohydrate content of gluten-free bread varied from 74.14 to $78.31 \%$, was found to be the highest in $\mathrm{T}_{3}$ while $\mathrm{T}_{1}$ showed the lowest values probably due to use the rice flour and barley flour, respectively. The different proximal composition of gluten-free bread commercial samples studies could be affected by many factors such as the wide range of complex ingredients added and their combinations, besides the additives used to improve the structure, mouth feel, acceptability and shelf-life of these products $[43,47]$.

\subsection{Sensory evaluation}

The sensory analysis showed significant differences $(p<0.05)$ among the different experimental breads for the different attribute like color, flavor, texture, taste and overall acceptability (Table 4). Results highlighted that the addition of hydrocolloids (Xanthan gum) and whole egg improved the sensorial quality of gluten-free breads in most of the cases. In fact, the sensorial data showed that the treatment $\mathrm{T}_{3}$ with the use of rice flour bread presented the best results, higher color, flavor, texture and taste, followed by barley and corn flour, as shown in Table 4. According to Machado [48], the texture is considered one of the most important aspects of bread quality, which is influenced by the granulation or structure of the crumb. With regard to the overall acceptability, $\mathrm{T}_{3}$ sample was the more acceptable to the panelist, while $\mathrm{T}_{1}$ and $\mathrm{T}_{2}$ samples were the lowest acceptable sample. However, the bread prepared with corn flour was considered good as taste and overall acceptability and barley flour bread was considered better as color.

Table 4. Sensory evaluation of the breads by consumer's test.

\begin{tabular}{llllll}
\hline \multirow{2}{*}{ Treatment Code } & \multicolumn{2}{l}{ Sensory attributes } & & \\
\cline { 2 - 5 } & Color & Flavor & Texture & Taste & $\begin{array}{l}\text { Overall } \\
\text { Acceptability }\end{array}$ \\
\hline $\mathrm{T}_{1}$ & $7.57 \pm 1.1^{\mathrm{a}}$ & $6.89 \pm 1.5^{\mathrm{a}, \mathrm{b}}$ & $5.7 \pm 1.6^{\mathrm{b}}$ & $5.6 \pm 1.3^{\mathrm{b}}$ & $4.8^{\mathrm{b}} \pm 1.1^{\mathrm{b}}$ \\
$\mathrm{T}_{2}$ & $6.46 \pm 1.2^{\mathrm{b}}$ & $6.6 \pm 1.5^{\mathrm{b}}$ & $6.46 \pm 1.6^{\mathrm{b}}$ & $6.9 \pm 1.3^{\mathrm{a}}$ & $5.8 \pm 1.1^{\mathrm{a}}$ \\
$\mathrm{T}_{3}$ & $7.71 \pm 1.3^{\mathrm{a}}$ & $7.7 \pm 1.7^{\mathrm{a}}$ & $7.61 \pm 1.7^{\mathrm{a}}$ & $7.21 \pm 1.6^{\mathrm{a}}$ & $6.1 \pm 1.2^{\mathrm{a}}$
\end{tabular}

Mean value \pm standard deviations of three replicates. Values labeled with a different letter in the same column are significantly different $(p<0.05)$. Barley flour based: $\mathrm{T}_{1}$; Corn flour based: $\mathrm{T}_{2}$; Rice flour based: $\mathrm{T}_{3}$.

\subsection{Conclusions}

The results of the current study show that it is possible to formulate gluten-free breads with good baking characteristics, while the use of rice flour ( $\mathrm{T}_{3}$ ) in the recipe leads to breads with good quality specific volume, ideal moisture and low bake loss. Bread with rice flours showed good chemical characteristics and an adequate sensory profile. Corn flour generated batter with good sensory properties, however its breads generally presented poor characteristics. For rice flour breads $\left(\mathrm{T}_{3}\right)$ good results were obtained, in all parameters studied indicating that these ingredients could be a promising alternative to wheat flour. The approach demonstrated in the present work could also serve as a stepping stone to the production of other gluten-free bakery products such as cake and muffins. Further microbial and rheological research is needed to complete the application study of different flours on gluten-free breads. However, regarding the current increasing awareness of celiac disease due to superior diagnostic methods, more comprehensive researches in the field of glutenfree cereal-based products are necessary. 


\subsection{Acknowledgements}

The authors would like to express their sincere thanks and heartiest gratitude to the Food Engineering and Technology (FET) Laboratory of Hajee Mohammad Danesh Science and Technology University (HSTU), Dinajpur, Bangladesh, for facilitating the physical and chemical tests.

\subsection{References}

[1] K. Katina, E. Arendt, K.H. Liukkonen, K. Autio, L. Flander, and K. Poutanen, "Potential of sourdough for healthier cereal products", Trends in Food Science \& Technology, Vol. 16, Pp. 104-112, 2005.

[2] G.A. Heap, and D.A. Van Heel, "Genetics and Pathogenesis of celiac disease”, Seminars in Immunology, Vol. 21, Pp. 346-354, 2009.

[3] R.P. Zandonadi, R.B. Botelho, and W.M. Arajo, "Psyllium as a substitute for the gluten in bread", Journal of the American Dietetic Association, Vol. 109, No. 10, Pp. 1781-1784, 2009.

[4] M. Gobbetti, C.G. Rizzello, R. dicagno, and M. De Angelis, “Sour dough lactobacilli and celiac disease”, Food Microbiology, Vol. 24, Pp. 187-196, 2003.

[5] H. Gül, and F. Haylt, "Optimization of gluten-free bread Formulation by using response surface methodology”, Abstract Proceeding Book of International Conference on Agriculture, Forest, Food Sciences and Technologies (ICAFOF) Cappadocia / Turkey, Pp. $148,2017$.

[6] H. Gambus, M. Sikora, and R. Ziobora, "The effect of composition of hydrocolloids on properties of gluten-free bread", Acta Scientiarum Polonorum, Technologia Alimentaria, Vol. 6, No. 3, Pp. 61-74, 2007.

[7] E.K. Arendt, A. Morrissey, M.M. Moore, F. Dal Bello, “Gluten-free Breads. In: Gluten-Free Cereal Products and Beverages. Ed. Arendt E.K., Dal Bello F. Food Science and Technology”, International Series. Elsavier, Vol. 13, Pp. 289-319, 2008.

[8] D. Sabanis, D. Lebesi, and C. Tzia, "Effect of dietary fibre enrichment on selected Properties of gluten-free bread", In LWT - Food Science and Technology, Vol. 42, Pp. 1380-1389, 2009.

[9] R. Schoenlechner, I. Mandala, A. Kiskini, A. Kostaropoulos, and E. Berghofer, "Effect of water, albumen and fat on the quality of gluten-free bread containing amaranth", International Journal of Food Science and Technology, Vol. 45, Pp. 661-669, 2010.

[10] M.E. Matos, T. Sanz, and C.M. Rosell, "Establishing the function of proteins on the rheological and quality properties of rice-based gluten-free muffins", Food Hydrocolloids, Vol. 35, Pp. 150-158, 2014.

[11] S.W. Horstmann, C. Axel, and E.K. Arendt, "Water absorption as a prediction tool for the application of hydrocolloids In potato starch-based bread", Food Hydrocolloids, Vol. 81, Pp. 129-138, 2018.

[12] M. Pestoric, M. Sakac, L. Pezo, S. Dubravka, N. Nedeljkovic, P. Jovanov, O. Simurina, and A. Mandic, 2017. “Physicochemical characteristics as the markers In predicting the selflife of gluten-free cookies", Journal of Cereal Science, Vol. 77, Pp. 172-179.

[13] A.V. Shah, A.T.M. Serajuddin, and R.A. Mangione, "Making all medications gluten free”, Journal of Pharmaceutical Sciences, Vol. 107, Pp. 1263-1268, 2017.

[14] H. Gül, F. Hayıt, and H. Dizlek, “Problems with food Safety in gluten-free products”, 6th Food Safety Congress, 3-4 May 2018 , Istanbul/Turkey, 2018.

[15] N. Pellegrini, and C. Agostoni, "Nutritional aspects of Gluten-free products”, Journal of the Science of Food and Agriculture, Vol. 95, Pp. 2380-2385, 2015.

[16] F. Naqash, A. Gani, A. Gani, and F.A. Masoodi, “Gluten-free baking: Combating the challenges - A Review”, Trends in Food Science and Technology, Vol. 66, Pp. 98-107, 2017.

[17] Y. Gao, M.E. Janes, B. Chaiya, M.A. Brennan, C.S. Brennan, and W. Prinyawiwatkul, “Gluten-free bakery and pasta products: prevalence and quality Improvement”, International Journal of Food Science and Technology, Vol. 53, Pp. 19-32, 2018.

[18] M. Simić, S. Žilić, O. Šimuruna, B. Filipčev, D. Škrobot, and J. Vančetović, "Effects of anthocyanin-rich popping maize flour on the phenolic profile and the antioxidant capacity of mix-bread and its physical and sensory properties", Polish Journal of Food and Nutrition Sciences, Vol. 68, Pp. 299-308, 2018.

[19] T. Wandersleben, E. Morales, C. Burgos-Diaz, T. Barahona, E. Labra, M. Rubilar, and H. Salvo-Garrido, "Enhancement Of functional and nutritional properties of bread using a mix Of natural ingredients from novel varieties of flaxseed and lupine”, LWT - Food Science and Technology, Vol. 91, Pp. $48-54,2018$.

[20] 0. Nurul Ain, A.M. Marina, and H. Sakinah, "The effect of avocado puree as fat replacer on the physical quality of muffin", Malaysian Applied Biology, 45, Pp. 11-16, 2016.

[21] P. Itthivadhanapong, and A. Sangnark, "Effects of substitution of black glutinous rice flour for wheat flour on batter and cake properties", International Food Research Journal, Vol. 23, Pp. 1190-1198, 2016.

[22] C. Onyango, C. Mutunge, G. Unbehend, and M.G. Lindhauer, "Modification of gluten-free sorghum batter and bread using maize, potato, cassava or rice starch", LWT-Food Science and Technology, Vol. 44, Pp. 681-686, 2011.

[23] L.S. Sciarini, P.D. Ri botta, A.E. León, and G.T. Pérez, "Influence of gluten-free flours and their mixtures on batter properties and bread quality”, Food and Bioprocess Technology, Vol. 3, Pp. 577-585, 2010.

[24] L.T. Rodrigue z Furlán, A. Pérez Padilla, and M.E. Campderrós, "Improvement of gluten-free bread properties by the incorporation of bovine plasma proteins and different saccharides into the matrix", Food Chemistry, Vol. 170, Pp. 257-264, 2015.

[25] E. De la Hera, M. Talego' n, P. Caballero, and M. Go' mez, "Influence of maize flour particle size on gluten-free breadmaking”, Journal of the Science of Food and Agriculture, Vol. 93, Pp. 924-932, 2013. 
[26] E.K. Arendt, and Bello FD. 2008. Gluten-Free Cereal Products and Beverages. London, UK: Academic Press.

[27] J.L. Greene, and A.C. Bovell-Benjamin, "Macroscopic and sensory evaluation of bread supplemented with sweet potato flour", Journal of Food Science, Vol. 69, Pp. S167-S173, 2004.

[28] B. Minarro, E. Albanell, N. Aguilar, B. Guamis, and M. Capellas, "Effect of legume flours on baking characteristics of gluten-free bread", Journal of cereal science, Vol. 56, Pp. 476-481, 2012. Doi: 10.1016/j.jcs.2012.04.012

[29] AOAC: Official methods of analysis, 18th edn. Gaithersburg Association of Official Analyyical Chemists International, 2006.

[30] A. Kramer, and B.A. Twigg, "Fundamentals of quality control for the food industry”, avi-Publishing Co, west Port, CT, 1974.

[31] K. Tronsom, E. Faergestad, J. Schofield, and E. Magnus, "Wheat protein quality in relation to baking performance evaluated by the chorleywood bread process and a health bread baking test", Journal of cereal science, Vol. 38, Pp. 205-215, 2003.

[32] H. He, and R.C. Hoseney, “Gás retention of different cereal flours”, Cereal Chemistry, Vol. 68, Pp. 334-336, 1991.

[33] G.A.A. Shehry, "Use of corn and quinoa flour to produce bakery products for celiac disease”, Advances in Environmental Biology, Vol. 10, No. 12, Pp. 237-244, 2016.

[34] A.A.M. Abou-Zaid, T.R. Mostafa, and S.A. Alasklany, "Utilization of faba bean and cowpea flours in gluten free cake production", Australian Journal of Basic and Applied Sciences, Vol. 5, No. 12, Pp. 2665-2672, 2011.

[35] M. Gomez, S. Del Real, C. Rosell, F. Ronda, and C. Blanco, "Functionality of different emulsifiers on the performance of bread making and wheat bread quality", European Food Research and Technology, Vol. 219, Pp. 145-150, 2004.

[36] L.M.P. Machado, "Pão sem glúten: Otimização de algumas variáveis de processamento. Campinas: Universidade Estatual de Campinas”, (Dissertação de Mestrado em Tecnologia de Alimento), Pp. 186, 1996.

[37] S.A. Matz, “Testing of bakery products Bakery technology engineering”, Westport, Pp. 614-620, 1960.

[38] T. Rakcejeva, R. Galoburda, L. Cude, and E. Strautniece, “Use of dried pumpkins in wheat bread production”, Procedia Food Science, Vol. 1, Pp. 441$447,2011$.

[39] D. Pastuszka, H. Gambuś, R. Ziobro, K. Buksa, S.R.T. Grażyna, “Impact of oats $\beta$-glucans on properties of gluten-free bread. Journal of Microbiology”, Biotechnology and Food Sciences, 1 (February Special issue), Pp. 972-979, 2012.

[40] A.M.S. Hussein, M.M. Kamil, N.A. Hegazy, and S.A.H. Aboelnor, "Effect of Wheat Flour Supplemented with Barely and/or Corn Flour on Balady Bread Quality”, Polish Journal of Food and Nutrition Sciences., Vol. 63, No. 1, Pp. 11-18, 2013.

[41] M. Jancurová, L. Minarovicová, and A. Dandár, "Rheological properties of doughs with buckwheat and quinoa additives", Chemical Papers, Vol. 63, No. 6, Pp. 738-741, 2009.

[42] L. Abugoch, N. Romero, C. Tapia, J. Silva, and M. Rivera, "Study of some physicochemical and functional properties of quinoa (Chenopodium quinoa Willd.) Protein isolates”, Journal of Agricultural Food Chemistry, Vol. 56, Pp. 4745-4750, 2008.

[43] C. Marco, and C.M. Rosell, “Breadmaking performance of protein enriched, gluten-free breads”, European Food Research and Technology, Vol. 227, Pp. 1205-1213, 2008b.

[44] M.M. Moore, T.J. Schober, P. Dockery, and E.K. Arendt, "Textural comparisons of gluten-free and wheat-based doughs, batters, and breads", Cereal Chemistry, Vol. 81, Pp. 567-575, 2004.

[45] A.I. Hegazy, M.S. Ammar, and M.I. Ibrahium, "Production of Egyptian Gluten-Free Bread”, World Journal of Dairy \& Food Sciences, Vol. 4, No. 2, Pp. 123128,2009

[46] N. Bilgiçli, "The utilization of buckwheat flour in gluten-free egg noodle production”, Journal of Food, Agriculture and Environment, Vol. 6, Pp. 113115,2008

[47] A. Lazaridou, D. Duta, M. Papageorgiou, N. Belc, and C.G. Biliaderis, "Effects of hydrocolloids on dough rheology and bread quality parameters in glutenfree formulations", Journal of Food Engineering, Vol. 79, Pp. 1033-1047, 2007.

[48] L.M.P. Machado, "Pão sem glúten: Otimização de algumas variáveis de processamento. Campinas: Universidade Estatual de Campinas. (Dissertação de Mestrado em Tecnologia de Alimento), Vol. 186, 1996. 